\title{
16th SHANGHAI INTERNATIONAL FILM FESTIVAL
}

\author{
By The Editor
}

Fall 2014 Issue of KINEMA

\section{6th SHANGHAI INTERNATIONAL FILM FESTIVAL}

Shanghai is playing an interesting hand early into its tenure as China's most established festival, shaped by the Chinese film industry's dynamic growth and the Beijing International Film Festival's upstart claim for national preeminence. It could play its ace in promoting Mainland Chinese films, yet Shanghai hasn't exploited this potential. This leaves Asian programming as its next best card, but Asian films at its 16th edition (15-23 June 2013) lacked range and vigour, especially in its fevered Japanese and Thai line-ups. Retrospectives felt more visible this year: apart from ones dedicated to Alfred Hitchcock, Ozu Yasujiro, Oliver Stone and Tang Xiaodan, Shanghai paid a nine-film tribute to the late singer-actor Leslie Cheung on his tenth anniversary. But organizers denied the same courtesy to Anita Mui, an equally talented hyphenate who also died in 2003, and whose amity and working rapport with Cheung certainly justified a shared tribute. Overall, here were ten notable titles:

As Time Goes by in Shanghai (Uli Gaulke, Germany/Netherlands 2013) Nostalgia of Shanghai's glorious past infuses Uli Gaulke's charming profile of the Peace Old Jazz Band, renowned as the world's oldest based on the average age of its six members. Although formed in 1980, most of the men have been performing since the 1940s and have thus witnessed good and bad times. As Gaulke follows preparations for their working trip to Rotterdam's North Sea Jazz Festival in 2011, the members ruminate between rehearsals on how China's transformation has sustained their passions and longevity. Without missing a beat, the band still plays nightly at the Peace Hotel, located off the Bund.

Cableway Doctor (Lei Xianhe, China 2012)

Set in the imposing mountains of Yunnan among the ethnic Lisu and Nu, Lei Xianhe's portrayal of a tireless door-to-door physician working his beat is a different kind of adventure film. Although the good doctor serves his community dutifully, his devotion is always at the expense of his family's welfare. Despite the perils of reaching his patients by crude cableways, his daily toils divide his extended kin. His son and sickly wife stand by him, but his brother-in-law shames him within the community for neglecting his family. The film's story is inspired by the life of 'cableway doctor' Deng Qiandui.

China Affair (Zhang Ming, China 2013)

Films about Western experiences of China can be touch-and-go affairs, but Zhang Ming's tale about a Sinophile American who abandons his travels on the Yangtze River to pursue a freewheeling woman in Wushan is alluring despite some fluff and fantasy. Much of the plot concerns how two overeager locals - a genial cop and a repressed secretary - help the smitten hipster locate his elusive object of desire. The film's lyrical Chinese title translates as "Their Names Are Hong" and refers to the two female leads whose contrasting feelings toward the American are key to forging this dreamy take on unrequited love.

Cold Bloom (Funahashi Atsushi, Japan 2012)

Funahashi Atsushi's finely crafted drama is set in a struggling hardware factory where a young newlywed is widowed when her colleague accidentally kills her husband. At first repulsed by the man's shame, the woman finds herself drawn to his penitence and desire for her. Inspired by the plot of Naruse Mikio's Scattered Clouds (1967), Funahashi's fifth feature was also tailored to honour the tsunami-hit coastal city of Hitachi where his story takes place. A political subplot involving the abuse of two Chinese immigrants is redundant and would have had greater resonance had one of them been cast as the interloper.

Farewell My Concubine (Chen Kaige, Hong Kong 1993)

Chen Kaige's landmark film has aged beautifully these 20 years, especially in view of its popularity in the festival's tribute to the late Leslie Cheung. Spanning the sweep of modern Chinese history and based on the 
eponymous opera, Chen's melodrama charts a love triangle between a prostitute (Gong Li) and two Beijing opera performers (Cheung and Zhang Fengyi). Although Cheung's avowed love for playing tragic heroes is typified here, his remarks in one interview about his character Cheng Dieyi are now forever laden with irony: "I wouldn't want to be him. I'm so happy I lead a more fortunate life."

Innocents (Wong Chen-hsi, Singapore 2012)

A brooding quiescence marks Chen Hsi-wong's assured debut feature about the fleeting nature of childhood. In a public primary school, a precocious young girl befriends her troubled male peer after others treat him as an outcast. In return he invites her to his hideaway located along a massive forested culvert, which soon becomes their refuge from the world of hostile adults. Set in the 1980s during a monsoon season, this is a rare Singaporean film in which the island is portrayed as a series of verdant open spaces - a visual metaphor for the loss of the city-state's innocence to urbanization.

Stilt (Tsai Yin-chuan, Taiwan 2012)

Tsai Yin-chuan's debut feature exposes a family's internal rot when two siblings of contrasting fortunes are forced to repair their differences at short notice. Coddled city-dweller Jiamin (James Wen) is a successful ornithologist whose avian obsession overrides his wife's (Bianca Bai) desire for greater intimacy and children. Country-rooted younger brother Jiaxiong (Chuang Kai-hsun) is a menial labourer who has purchased a reluctant Vietnamese bride (Helen Thanh Dao) to tend to their crusty mother - in a compelling subplot that deserves a spin-off. Although Tsai undercoats this ensemble portrait with compassion, she also tinges it with enough melodrama to stoke broad appeal.

Sunlight at Fingertips (Huang He, China 2012)

Huang He's second feature reveals the symptom of 'left-behind children' amid the rush of social changes sweeping the country. Set in the Wuling Mountains of Central China among the ethnic Tujia and Miao, a young brother and sister are raised by their blind grandfather while work holds their parents hostage in Shenzhen. To raise hopes of the many 'unattended' children like them, their school organizes a contest where winners can travel to cities to visit their parents. A sobering family film, its pathos is accented by the fact that the cast comprises children who have been 'left behind' in reality.

Touch (Min Byung-hun, South Korea 2012)

Min Byung-hun's engaging drama about redemption tells of a family fractured to the point of paralysis. A nurse (Kim Ji-young) burdened with holding her family together corruptly passes off elderly folks as abandoned persons to nursing homes. After her alcoholic husband (Yoo Jun-sang) gets into a car accident, she crosses more ethical lines with a hospital patient to raise the settlement for his victim. But the wife's misguided altruism is put to the ultimate test when their young daughter is raped and she is forced to confront the underage perpetrator's family. This is Min's first film in a planned trilogy.

A Young Girl's Destiny (An Zhanjun, China 2013)

A talented lass forsakes her job in England to realize her dream of becoming a television compère in Beijing, but is circled by hungry sharks the moment she dives into the entertainment industry. Set in the jianghu of showbiz, An Zhanjun's sprightly coming-of-age drama is a contemporary incarnation of the Wuxia genre, complete with a supporting cast of rogues and lowlifes. Zhang Lixin (a Tang Wei lookalike) deftly handles her part as the intrepid heroine, her charm matched only by Han Pengyi as her loyal suitor and Liu Xiaoye as her manager's eunuch-like henchman. The film's Chinese title translates as "Counterattack". 